\title{
DOES LIDOCAINE HAVE ANTIMICROBIAL EFFECTS AGAINST MAJOR PATHOGENS THAT INFECT WOUNDS? AN IN VITRO STUDY
}

Bruno Carvalho Henriques ${ }^{1}$, Isadora Delfino Caldeira ${ }^{1}$, Maria Júlia Schadeck Portelinha ${ }^{1}$, Denis Aloísio Lopes Medina $^{1}$, Cesar Alberto Talavera Martelli ${ }^{1}$, Mayla Silva Cayres de Oliveira ${ }^{2}$, Mércia de Carvalho Almeida ${ }^{1}$, Mariângela Esther Alencar Marques ${ }^{3}$, Gisele Alborghetti Nai ${ }^{1}$

${ }^{1}$ Universidade do Oeste Paulista - UNOESTE, Faculdade de Medicina, Presidente Prudente, SP. ${ }^{2}$ Universidade do Oeste Paulista - Laboratório de Análises Clínicas, Presidente Prudente, SP. ${ }^{3}$ Universidade Estadual Paulista - UNESP, Faculdade de Medicina de Botucatu, Botucatu, SP. E-mail: patologia@unoeste.br

\section{ABSTRACT}

Local anesthetics are commonly used in medicine and dentistry and have a low cost, but their action as a microbicidal agent is still controversial. This study aimed to evaluate the antimicrobial effects of lidocaine against bacteria that most commonly infect surgical wounds. We evaluated Staphylococcus aureus, Staphylococcus epidermidis, Escherichia coli, Proteus mirabilis and Enterococcus faecalis. The solutions tested were saline, chlorhexidine, lidocaine (solution and pure) and an antibiotic solution. The agar diffusion test was performed using Petri dishes. The agar plates were made in duplicate and incubated in an oven at $37^{\circ} \mathrm{C}$ for $48 \mathrm{~h}$. Subsequently, the inhibition halos were measured. The plates tested with lidocaine (pure or solution) presented no inhibition halo. The antibiotic solution presented the largest inhibition halos for all the bacteria $(p<0.05)$. Chlorhexidine formed an inhibition halo similar to that of the antibiotic solution for Escherichia coli $(p>0.05)$. Lidocaine did not present an antimicrobial effect for any of the tested bacteria. However, the antibiotic solution and the chlorhexidine inhibited the growth of all bacteria.

Keywords: anti-bacterial agents, bacteria, wound infection, anesthetics, prostheses and implants.

\section{A LIDOCAÍNA TEM EFEITO ANTIMICROBIANO FRENTE AOS PRINCIPAIS PATÓGENOS QUE INFECTAM FERIDAS? UM ESTUDO IN VITRO}

\section{RESUMO}

Os anestésicos locais são comumente usados em medicina e odontologia e têm baixo custo, mas sua ação como agente microbicida ainda é controversa. Este estudo teve como objetivo avaliar os efeitos antimicrobianos da lidocaína contra bactérias que mais comumente infectam feridas cirúrgicas. Foram avaliados Staphylococcus aureus, Staphylococcus epidermidis, Escherichia coli, Proteus mirabilis e Enterococcus faecalis. As soluções testadas foram solução salina, clorexidina, lidocaína (solução e pura) e uma solução antibiótica. $O$ teste de difusão em ágar foi realizado com placas de Petri. As placas de ágar foram feitas em duplicata e incubadas em estufa a $37^{\circ} \mathrm{C}$ por $48 \mathrm{~h}$. Posteriormente, os halos de inibição foram medidos. As placas testadas com lidocaína (pura ou solução) não apresentaram halos de inibição. $A$ solução antibiótica apresentou os maiores halos de inibição para todas as bactérias $(p<0,05)$. A clorexidina formou um halo de inibição semelhante ao da solução antibiótica para Escherichia coli $(p>0,05)$. A lidocaína não apresentou efeito antimicrobiano para nenhuma das bactérias testadas. Entretanto, a solução antibiótica e a clorexidina inibiram o crescimento de todas as bactérias.

Palavras-chave: agentes antibacterianos, bactérias, infecção dos ferimentos, anestésicos, próteses e implantes. 


\section{INTRODUCTION}

Surgical site infections are common, with an incidence of $1.5 \%$ to $5 \%$ for all types of surgery ${ }^{1}$. Although more than $99 \%$ of surgical patients receive prophylactic antibiotics, the incidence of postoperative infections remains high, negatively impacting patient outcomes and increasing health costs from $\$ 1$ to $\$ 10$ billion per year $^{1}$.

The bacteria that most commonly infect wounds of the most diverse types are Staphylococcus aureus, Proteus mirabilis, Escherichia coli, Staphylococcus epidermidis, Pseudomonas aeruginosa, Corynebacterium spp., coagulase-negative staphylococci and Klebsiella spp. $^{2-4}$. Staphylococcus aureus is the most incident bacterium independent of the type and location of the wound and is therefore also the most evaluated bacterium in relation to antimicrobial agents. The incidences of the other bacteria are influenced by the type and location of the wound ${ }^{2-4}$.

Infection is detrimental to wound healing, and infection of a wound plays a major role in the development of chronicity, delaying cures ${ }^{2}$. The diagnosis and treatment of wound infections are controversial and vary among clinicians ${ }^{5}$.

The efficacy of other treatments, in addition to antibiotic therapy, for bacterial infections has been evaluated in both medicine and dentistry ${ }^{6}$, in order to reduce their incidence and repercussions.

There is evidence to suggest that local anesthetics have inherent antimicrobial properties against a broad spectrum of human pathogens. Multiple local anesthetics at concentrations typically used in clinical settings inhibit the growth of various bacteria and fungi under a variety of conditions ${ }^{7}$.

Infections of surgical sites are common, even in patients using prophylactic antibiotic therapy. This causes morbidity and a possible decrease in the quality of life for patients, in addition to higher costs associated with their treatment. Local anesthetics are commonly used as an agent for preoperative analgesia in medicine and dentistry and have a low cost, but their action as a microbicidal agent is still controversial.

The aim of this study was to evaluate whether lidocaine has an antimicrobial effect against infection caused by the bacteria species that most commonly infect surgical wounds compared to the usual therapies.

\section{METHODOLOGY}

The following bacterial strains were used in the study (Microbiologics, Inc., St. Cloud, Minnesota, USA):

- Staphylococcus aureus subspecies aureus ATCC $25923^{\mathrm{Tm}}$

- Staphylococcus epidermidis ATCC $12228^{\mathrm{TM}}$

- Escherichia coli ATCC ${ }^{\circledR} 25922^{\text {TM }}$

- Proteus mirabilis ATCC ${ }^{\circledR} 25933^{\mathrm{Tm}}$

- Enterococcus faecalis ATCC ${ }^{\circledR} 29212^{\mathrm{TM}}$

Sterile saline microorganism suspensions were adjusted to the turbidity corresponding to 0.5 in the McFarland scale $\left(1.5 \times 10^{8}\right.$ colony forming units).

The solutions used were: Pure lidocaine ( $2 \%$ lidocaine without vasoconstrictor, HipoLabor, Brazil); Lidocaine solution: $20 \mathrm{~mL}$ of lidocaine (lidocaine $2 \%$ without vasoconstrictor, HypoLabor, Brazil) to $500 \mathrm{~mL}$ of saline solution ${ }^{8}$; Antiseptic used was $0.5 \%$ chlorhexidine digluconate (Indústria Farmacêutica Rioquímica Ltda, São José do Rio Preto, São Paulo, Brazil); Antibiotic solution: made with $1 \mathrm{~g}$ of cefazolin sodium (Fazolon ${ }^{\circledR}$, Blau Pharmaceuticals SA, São Paulo, SP, Brazil) and $80 \mathrm{mg}$ of gentamicin sulfate (gentamicin, Nova Farma Indústria Farmacêutica Ltda., Anápolis, GO, Brazil) diluted in $100 \mathrm{~mL}$ of saline solution $(0.9 \% \mathrm{NaCl})^{9}$.

The agar diffusion test was performed using $15 \times 150 \mathrm{~mm}$ Petri dishes containing approximately $40 \mathrm{~mL}$ of Mueller-Hinton agar (for the evaluation of Proteus mirabilis) or $40 \mathrm{~mL}$ of blood agar (for the evaluation of all other bacteria). The microorganism suspensions (Staphylococcus aureus, Staphylococcus epidermidis, Escherichia coli, Proteus mirabilis and Enterococcus faecalis) were inoculated with the aid of sterile swabs on the surface of the agar. Afterwards, holes measuring $3 \mathrm{~mm}$ in diameter and $3 \mathrm{~mm}$ deep were made in the agar. Separate plaques received one drop $(5 \mu \mathrm{L})$ of each solution in the orifice (saline, chlorhexidine, lidocaine solution, pure lidocaine and antibiotic solution). The agar plates were made in duplicate and incubated in an oven at $37^{\circ} \mathrm{C}$ for $48 \mathrm{~h}^{6}$. Plate reading was performed using a millimeter ruler to measure the diameter of the inhibition halos.

\section{Statistical analysis}

Analysis of variance was used for each of the solutions to test the mean of the inhibition halos between the different bacteria and then use the Tukey multiple comparisons test to identify for which bacteria the solutions were 
most effective. The level of significance was set at $5 \%$, and SPSS V.22 software was used to perform the analyses.

\section{RESULTS}

Saline, pure lidocaine and the lidocaine solution did not form inhibition halos for any of the bacteria evaluated (Figure 1).

The largest inhibition halos were observed for the antibiotic solution $(p<0.001)$
(Figure 1 and Figure 2), except for the evaluation of plaques inoculated with Escherichia coli, where chlorhexidine produced an inhibition halo similar to that of the antibiotic solution ( $p>0.05$ ).

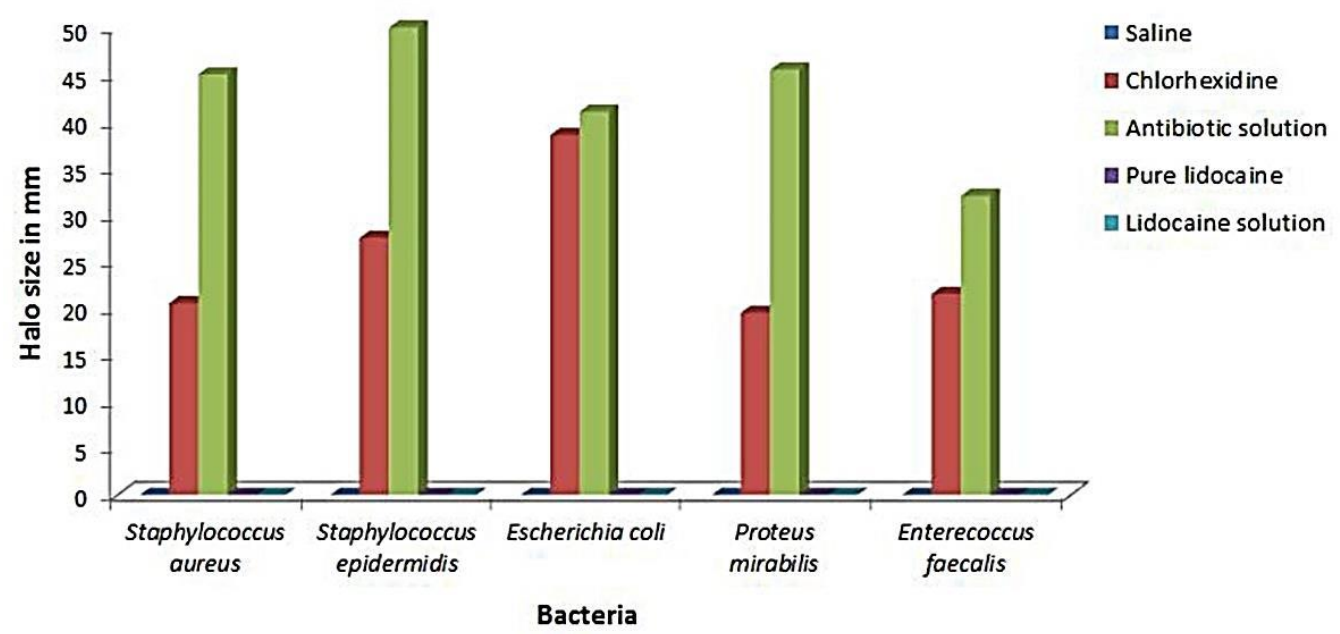

Figure 1. Mean inhibition halo size in millimeters $(\mathrm{mm})$ according to the bacteria and the inhibitory agent used.

Regarding the analysis of the inhibition halo produced by chlorhexidine, there was a difference between the halo observed in the analysis of the plate containing Staphylococcus aureus and the halo observed in the plate containing Staphylococcus epidermidis $(\mathrm{p}=0.046)$ and the halo observed in the plate containing Escherichia coli $(p=0.001)$. The inhibition halo associated with Staphylococcus epidermidis differed from the halos associated with Escherichia coli $(\mathrm{p}=0.007)$ and Proteus mirabilis $(p=0.027)$, and the inhibition halo associated with Escherichia coli differed from the halos associated with all other bacteria $(p<0.05)$. The halo associated with Proteus mirabilis differed from the halos associated with Staphylococcus epidermidis $(\mathrm{p}=0.027)$ and Escherichia coli $(p=0.001)$, and the inhibition halo associated with Enterococcus faecalis differed only from the inhibition halo associated with Escherichia coli $(p=0.001)$.

\section{DISCUSSION}

In this in vitro study, the plates tested with a solution of lidocaine and pure lidocaine did not present inhibition halos. The antibiotic solution presented the highest inhibition halos in all of the bacteria tested. The chlorhexidine formed a halo with a size similar to that of the halo of the antibiotic solution for Escherichia coli.

The incidence of infected wounds and the scarcity of studies evaluating the antibacterial agents in relation to the other bacteria rather than Staphylococcus aureus directed the choice of those tested in this study.

Lidocaine, among the various formulations of local anesthetics, is the most commonly used in a plethora of small surgical procedures in dental practice, emergency rooms, outpatient clinics and surgical centers ${ }^{10}$. Lidocaine is an inexpensive and easily administrable anesthetic that is widely used by surgeons ${ }^{10}$. Therefore, its antimicrobial effect was tested in our study and in previous studies. 


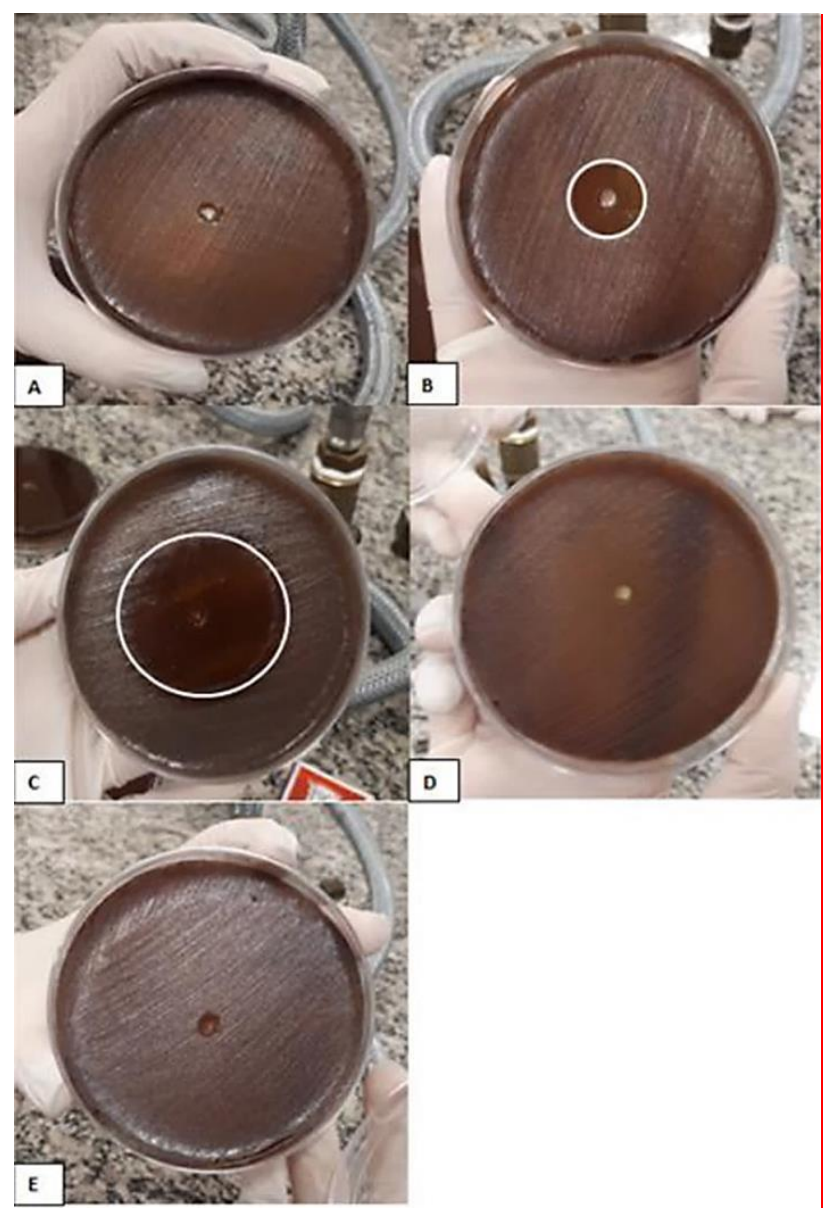

Figure 2. Analysis of Petri dishes seeded with Staphylococcus aureus: A: Saline. B: Chlorhexidine digluconate. C: Antibiotic solution. D: Pure Lidocaine. E: Lidocaine solution. Culture medium: Blood agar. White marking indicates the inhibition halo.

In vivo models of surgical wound dressing using lidocaine prior to the inoculation of Staphylococcus aureus ${ }^{10}$ and with continuous infusion of lidocaine in Staphylococcus aureusinfected wounds ${ }^{11}$ demonstrated a decrease in the bacterial counts of animals treated with this anesthetic. However, other studies have not shown any antimicrobial activity of local anesthetics and their combinations in surgical wounds of rats infected with Staphylococcus aureus $^{1,12}$. In our study, lidocaine (pure or in solution) had no antimicrobial effect for any of the bacteria tested. Lidocaine probably has no antibacterial effect but rather a tissue effect, vasodilation activity or even proinflammatory activity. There are anesthetics, such as ketamine (a dissociative anesthetic), which are known to have anti-inflammatory effects ${ }^{13}$ and influence the course of infectious processes.
A fact that reinforces the probable tissue activity of lidocaine is the fact that a study observed a significant decrease in the Staphylococcus aureus count of lidocaine-treated animals as well as a 20 -fold increase with the addition of epinephrine (a vasoconstrictor) compared to a control group ${ }^{10}$. This could justify the absence of antimicrobial action in our study that was performed in vitro. In addition, it may also justify the antimicrobial activity observed in some in vivo studies and not in others.

Antimicrobial prophylaxis is the main pharmacological measure effective in reducing the risk of infection at the surgical site ${ }^{14}$. In the present study, the solution combining two antibiotics (cefazolin sodium and gentamicin sulfate) presented the best antimicrobial effect, forming large inhibition halos, as expected, even when the two antibiotics were diluted in saline solution.

In this study, chlorhexidine, a commonly used antiseptic solution used in medicine and dentistry $^{6,15}$, showed an antimicrobial effect for all of the bacteria tested, but with inhibition halo formation approximately $40 \%$ smaller than that of the antibiotic solution. In our study, the exception occurred for the analysis of plates inoculated with Escherichia coli, where the halo formed by chlorhexidine was only $6 \%$ smaller than that formed by the antibiotic solution. These data show that the antimicrobial effect is dependent on the bacteria evaluated not only for antibiotics but also for antiseptics.

More in vivo studies focusing on the possible tissue actions of lidocaine and inflammatory cytokine responses are necessary to determine whether lidocaine may or may not help in the prophylaxis of surgical wound infections.

On the basis of the data obtained from this study, we conclude that lidocaine does not present an in vitro antimicrobial effect. However, the antibiotic solution has a good antimicrobial effect against the bacteria tested, as does chlorhexidine to a lesser extent, showing that these two substances can be used to prevent these infections.

\section{ACKNOWLEDGMENTS}

This study was funded with financial aid by Universidade do Oeste Paulista. The authors acknowledge Ligia Maria Delfino Caldeira and Denise Lopes da Costa from the Laboratory of 
Clinical Analysis of Universidade do Oeste Paulista for their support during this research.

\section{CONFLICT OF INTEREST}

The authors declare that there is no potential conflict of interest that could interfere with the impartiality of this scientific work.

\section{REFERENCES}

1. Sams VG, Lawson CM, Coan P, Bemis D, Newkirk K, Karlstad M, Norwood J, Barlow $\mathrm{P}$, Goldman $\mathrm{MH}$, Daley BJ. Effect of local anesthetic on microorganisms in a murine model of surgical site infection. J Trauma Acute Care Surg. 2012;73:441-5.

DOI: http://dx.doi.org/10.1097/TA.0b013e3182583e4f

2. Bessa LJ, Fazii P, Di Giulio M, Cellini L. Bacterial isolates from infected wounds and their antibiotic susceptibility pattern: some remarks about wound infection. Int Wound J. 2015;12:47-52. DOI: http://dx.doi.org/10.1111/iwj.12049

3. Mengesha RE, Kasa BG, Saravanan M, Berhe DF, Wasihun AG. Aerobic bacteria in post-surgical wound infections and pattern of their antimicrobial susceptibility in Ayder Teaching and Referral Hospital, Mekelle, Ethiopia. BMC Res Notes. 2014;7:575. DOI: http://dx.doi.org/10.1186/1756-0500-7-575

4. Turtiainen J, Hakala T, Hakkarainen T, Karhukorpi J. The impact of surgical wound bacterial colonization on the incidence of surgical site infection after lower limb vascular surgery: a prospective observational study. Eur J Vasc Endovasc Surg. 2014;47:411-7. DOI: http://dx.doi.org/10.1016/i.ejvs.2013.12.025

5. Edwards R, Harding KG. Bacteria and wound healing. Curr Opin Infect Dis. 2004;17:91-6.

6. Davis JM, Maki J, Bahcall JK. An in vitro comparison of the antimicrobial effects of various endodontic medicaments on Enterococcus faecalis. J Endod 2007;33:567-9. DOI: http://dx.doi.org/10.1016/i.joen.2007.01.015

7. Johnson SM, Saint John BE, Dine AP. Local anesthetics as antimicrobial agents: a review. Surg Infect (Larchmt). 2008;9:205-13. DOI: http://dx.doi.org/10.1089/sur.2007.036
8. Thomas DF, Lambert WG, Williams KL. The direct perfusion of surgical wounds with local anaesthetic solution: an approach to postoperative pain? Ann R Coll Surg Engl. 1983;65:226-9.

9. Fernandes TRR, Okada A, Montag E, Almeida PN, Arruda EGP, Ferreira MC. Infecção em reconstrução mamária com expansor/prótese: incidência e correlação com fatores de risco em 120 pacientes. Rev Bras Cir Plast. 2012;27:1-102.

10. Stratford AF, Zoutman DE, Davidson JS. Effect of lidocaine and epinephrine on Staphylococcus aureus in a guinea pig model of surgical wound infection. Plast Reconstr Surg. 2002;110(5):12759.

11. Lu CW, Lin TY, Shieh JS, Wang MJ, Chiu KM. Antimicrobial effect of continuous lidocaine infusion in a Staphylococcus aureus-induced wound infection in a mouse Model. Ann Plast Surg. 2014;73:598-601.

DOI: http://dx.doi.org/10.1097/SAP.0b013e318276d8 e7

12. Kose $A A$, Karabaggli $Y$, Kiremitci $A$, Kocman $E$, Cetin C. Do local anesthetics have antibacterial effect on Staphylococcus aureus under in vivo conditions? An experimental study. Dermatol Surg. 2010;36:848-52.

DOI:

http://dx.doi.org/10.1111/j.15244725.2010.01559.x

13. Helmer KS, Cui Y, Chang L, Dewan A, Mercer DW. Effects of ketamine/xylazine on expression of tumor necrosis factor-alfa inducible nitric oxide synthase, and cyclo-oxygenase- 2 in rat gastric mucosa during endotoxemia. Shock. 2003;20:639.

14. Young PY, Khadaroo RG. Surgical site infections. Surg Clin North Am. 2014;94(6):1245-64. DOI: http://dx.doi.org/10.1016/j.suc.2014.08.008

15. Staneviciute E, Na'amnih W, Kavaliauskas $P$, Prakapaite R, Ridziauskas $M$, Kevlicius L, Kirkliauskiene A, Zabulis V, Urboniene J, Triponis V. New in vitro model evaluating antiseptics' efficacy in biofilm-associated Staphylococcus aureus prosthetic vascular graft infection. J Med Microbiol. 2019;68:432-9. DOI: 